\title{
The Association of Serum and Forage Copper Levels and Blood Values of Grazing Goats of Different Physiological Stages Pertaining to Location in the Dry and Wet Seasons from Central Trinidad
}

\section{Aphzal Mohammed ${ }^{\mathrm{a}^{*}}$; Mervyn Campbell ${ }^{\mathrm{b}}$; Indira Pargass ${ }^{\mathrm{b}}$; Shenese Sieuchand ${ }^{\mathrm{a}}$; Puran Bridgemohan $^{\mathrm{a}}$; Angelisah Khan ${ }^{\mathrm{a}}$; Fayez Youssef ${ }^{\mathrm{c}}$}

${ }^{a *}$ The University of Trinidad and Tobago, Eastern Caribbean Institute of Agriculture and Forestry, Faculty of Biosciences; Agriculture and Food Technology, Caroni North Bank Road, Centeno Arima, Trinidad;

aphzal.mohammed@utt.edu.tt

${ }^{\mathrm{b}}$ Systemic Pathologist School of Veterinary Medicine, Faculty of Medical Sciences The University of the West Indies (UWI), Mt. Hope, Trinidad, West Indies

vynmer@yahoo.com

${ }^{\mathrm{b}}$ Clinical Pathologist School of Veterinary Medicine, Faculty of Medical Sciences The University of the West Indies (UWI), Mt. Hope, Trinidad, West Indies;

indira.pargass@sta.uwi.edu

apuran.bridgemohan@utt.edu.tt; ${ }^{a}$ shenese.sieuchand@utt.edu.tt; ${ }^{a}$ angelisah.khan@utt.edu.tt

${ }^{c}$ Retired Senior Lecturer, department of Food Production The University of the West Indies (UWI), St Augustine, Trinidad, West Indies

\begin{abstract}
A study was conducted to determine hematological values of 153 grazing goats, pertaining to physiological stage, in the late dry and late wet seasons of Central Trinidad. Goats had lower $(P<0.01)$ haemoglobin $(\mathrm{Hb})$ and packed cell volume $(\mathrm{PCV})$ values in the wet than in the dry season. $41 \%$ of goats in the wet season exhibited a non-regenerative anaemia $(\mathrm{Hb}<80 \mathrm{~g} / \mathrm{L} ; \mathrm{PCV}<0.22 \mathrm{~L} / \mathrm{L} ;$ reticulocyte count $<1 \%)$. At one particular farm location lowest forage and serum copper levels and an accompanying highest incidence of non - regenerative anaemia was observed. Also, hemoglobin and packed cell volume values varied $(P<0.001)$ including lymphocyte $(P<0.001)$ counts among growing goats compared with other physiological stages. Significant variations occurred among these stages in the white blood cell count $(P<0.05)$ in goats. A moderate basophilia and eosinophilia was found in both seasons in goats. Highest haemoglobin and packed cell volume, white blood cell counts and lymphocyte values in growing goats compared with other stages was probably age related. Copper supplementation including adequate anthelmintic control is recommended for the prevention of anaemia and to optimize goat and sheep production of Central Trinidad.
\end{abstract}

Keywords: anemia; eosinophilia; basophilia, serum copper

\section{INTRODUCTION}

Trinidad and Tobago are two adjacent islands located northeast of the Venezuelan coast. The republic is located between latitudes $10^{\circ}$ and $11^{\circ}$ north and spans a longitude of $61^{\circ}$ west, has a combined area of $5070 \mathrm{~km}^{2}$, and a population of approximately 1.3 million inhabitants. The dry season is from January to May/June and the wet season is from July to December with sporadic rainfall patterns in both seasons. The domestic goat industry in Trinidad is primarily a subsistence industry with probably no more than 10,000 heads, with most farms having between 1 to 10 animals. (Mohammed, 1999). About $50 \%$ of the animals reared are of a nondescript local type whereas the remaining animals are pure bred or interbred crosses of Saanen, Alpine, and Anglo Nubian breed types. Most animals are kept indoors at night but allowed to graze on marginal lands foraging on native grasses during the day. 
Grazing ruminants depend largely on native forages to supply their nutrient requirements for growth and production. However, tropical grasses are frequently deficient in energy, protein and minerals with the culminating effect of low animal productivity. Copper $(\mathrm{Cu})$ is the major trace mineral limiting production of grazing animals in African, Asian, and Latin America countries (McDowell and Arthington, 2005). $\mathrm{Cu}$ is required for the function of over 30 proteins including superoxide dismutase, ceruloplasmin (EC1.16.3.1.), lysyl oxidase, cytochrome c oxidase, tyrosinase, dopamine- $\beta$ hydroxylase and hephaestin (S) (Prohaska, 2011). Copper functions as an electron transfer intermediate in redox reactions, and is therefore an essential cofactor for oxidative and reductive enzymes (Suttle, 2012).

Hephaestin, cytochrome C oxidase (EC 1.9.3.1) and ceruloplasmin (EC 1.16.3.1) are required for iron transport and are therefore closely aligned in functionality during erythropoiesis. Hephaestin is involved in the release of iron from intestinal enterocytes and into the blood. Cytochrome c oxidase is involved in reduction of ferric iron to the ferrous form for use in haeme synthesis (Schlams Veterinary Haematology, 2010). Ceruloplasmin (Cu oxidase) facilitates mobilization of iron from the liver and tissues other than enterocytes (Schlams Veterinary Haematology, 2010) as well binding of iron to the iron transport protein transferrin (Suttle, 2012). Cu deficiency results in decreased concentrations of these $\mathrm{Cu}$-containing proteins, and in turn resulting in a functional copper-related iron deficiency. Affected animals generally display a microcytic hypochromic anaemia (Schlams Veterinary Haematology, 2010). Williams et al. (1985) found that reduced cytochrome $\mathrm{C}$ oxidase activity in liver hepatocytes and bone marrow erythroid cells contributed to impaired haeme synthesis and therefore to the anaemia that is sometimes observed with $\mathrm{Cu}$ deficiency. In lambs and calves, $\mathrm{Cu}$-deficient diets $(<1 \mathrm{mg} \mathrm{Cu} / \mathrm{kgDM})$ can cause a marked or marginal decline in haemoglobin and packed cell volume levels (Howell, 1968b; Mills et al., 1976), resulting in anaemia which is microcytic, hypochromic, and non-regenerative or poorly regenerative (reticulocyte count of less than 1\%) (Thrall et al., 2004).

Haematological analysis is therefore an important tool to monitor the health status of animals, as well as for the diagnosis, treatment and prognosis of diseases. It is also a good method to monitor the physiologic changes that occur during pregnancy, parturition, and lactation, as blood parameters can be altered by several factors, including age, breed, health status, nutritional status, and physiologic status (Mbassa and Poulsen, 1992; Sharma et al., 2015; Njidda, et al., 2014). Other common factors affecting haematologic parameters in the tropics are season (Adewuyi and Adu, 1984; Mahieu et al., 2007) and the presence of parasitic infection (Morris and Dunn, 1992). Adewuyi and Adu (1984) found low packed cell volume (PCV) and haemoglobin $(\mathrm{Hb})$ values in certain West African sheep breeds at the end of the rainy season in Nigeria. Low PCV values in sheep and goats in the tropics during the rainy season was presumably associated with increased parasitic infection (Lutu, 1983; Omeke, 1988). In one study, oral dosing with L3 larvae of Haemonchus contortus in West African Dwarf goats resulted in a normochromic normocytic anaemia which was due to blood loss caused by this gastrointestinal parasite (Ameen et al., 2010).

Regarding age and physiological stage, higher $\mathrm{Hb}$ and PCV values are reported for 6-12 month old lambs (Mohammed et al., 2014) and kids (Mbassa and Poulsen, 1992) compared with pregnant and lactating animals. Pregnant goats from hot climates however, can exhibit higher PCV values than lactating animals, attributed to haemoconcentration (Habibu et al., 2014). In contrast, haemoglobin values and PCV values in sequentially monitored goats and sheep during pregnancy and onwards, generally reflect a rise in these values in late gestation, a decline in the periparturient period, followed by a rise at parturition and then a decline in early lactation (Azab and Abdel- Maksoud, 1999; El Sherif and Assad, 2001; Iriadam, 2007). The decline in Hb and PCV values in periparturient period is attributed to an increase in plasma volume (Jain, 1986). The decline in early to mid lactation is related to milk production (El- Deen et al., 1985b). Contrastingly, in West African Dwarf sheep, Obidike et al. (2009) did not find significant change in these values in the periparturient period except a rise at two weeks post parturition.

The white blood cell (WBC) and differential leucocyte counts in sheep and goats are also subject to variations due to age, physiologic stage and parasitic infection. Higher WBC and lymphocyte counts are found in kids less than 12 months of age compared with values in adult goats (Nettleton and Beckett, 1976; Mbassa and Poulsen, 1992). Additionally, total WBC may be elevated in late pregnancy in goats (Oduye, 1976) because of an ACTH hormonal stress reaction. Higher than normal eosinophil and sometimes basophil counts in growing and adult animals may be indicative of an 
The Association of Serum and Forage Copper Levels and Blood Values of Grazing Goats of Different Physiological Stages Pertaining to Location in the Dry and Wet Seasons from Central Trinidad

allergic response or recent parasitic infection (Morris and Dunn, 1992). An eosinophilia in lactating animals may be due to an allergic reaction to milk production (Jain, 1986).

In a farm investigative study of swayback prone farms in Central Trinidad, Mohammed (1999) found that $\mathrm{Cu}$ deficient kids and lambs had a non-regenerative anaemia. However it is not known whether an association exists between hematological values and blood serum $\mathrm{Cu}$ levels on goat farms in central Trinidad, from which there are no reported cases of swayback due to $\mathrm{Cu}$ deficiency. The purpose of this research was to study the effects of season and physiological stage on serum $\mathrm{Cu}$ levels and on certain haematological and plasma parameters of apparently normal goats. This study can provide useful information on whether hematological values of apparently normal goats are affected by season and physiological stage in relation to dietary $\mathrm{Cu}$ sufficiency.

\section{Materials ANd Methods}

\subsection{Farms and Management}

This study was carried out in the late dry (April- May) and late wet (November- December) seasons on four medium sized farms in Central and South Central Trinidad (Figure 1). Goats were reared partly indoors and semi-intensively at the Cunupia and Chaguanas farm locations. Goats were reared intensively at the Sugar Cane Feeds Centre, and semi-intensively at the Cunupia, Chaguanas and Couva farms. Goats were of Saanen and Anglo Nubian and scrub type origin. Goats were either 'zero grazed' or allowed to graze on local bamboo grass (Paspalum fasiculatum), para grass (Brachiaria mutica), tanner grass (Bracharia radicans), elephant grass (Pennesetum purpureum), pangola grass (Digitaria decumbens) cascadoux gras (Lersia hexandra) and acasia (Acacia mangium and leucaena (leucaena leucocephala). Goats at the Cunupia and Chaguanas locations were fed a mixture of bagasse $(40 \%)$, molasses $(30 \%)$, poultry by product meal $(10 \%)$, wheat middlings $(10 \%)$, urea $(1 \%)$, dicalcium phosphate $(1 \%)$ and sodium chloride $(0.5 \%)$. At all locations, goats were dewormed at weaning and in early pregnancy, either orally using oxfendazole at a dose rate of $5 \mathrm{mg} / \mathrm{kg}$ (Symantic; Syntex Agribusiness) or by sub-cutaneous injection with ivermectin (Ivomec; MSD Agvet) at a dose rate of $200 \mu \mathrm{g} / \mathrm{kg}$. Goats, except for pregnant animals were further dewormed at four times a year.

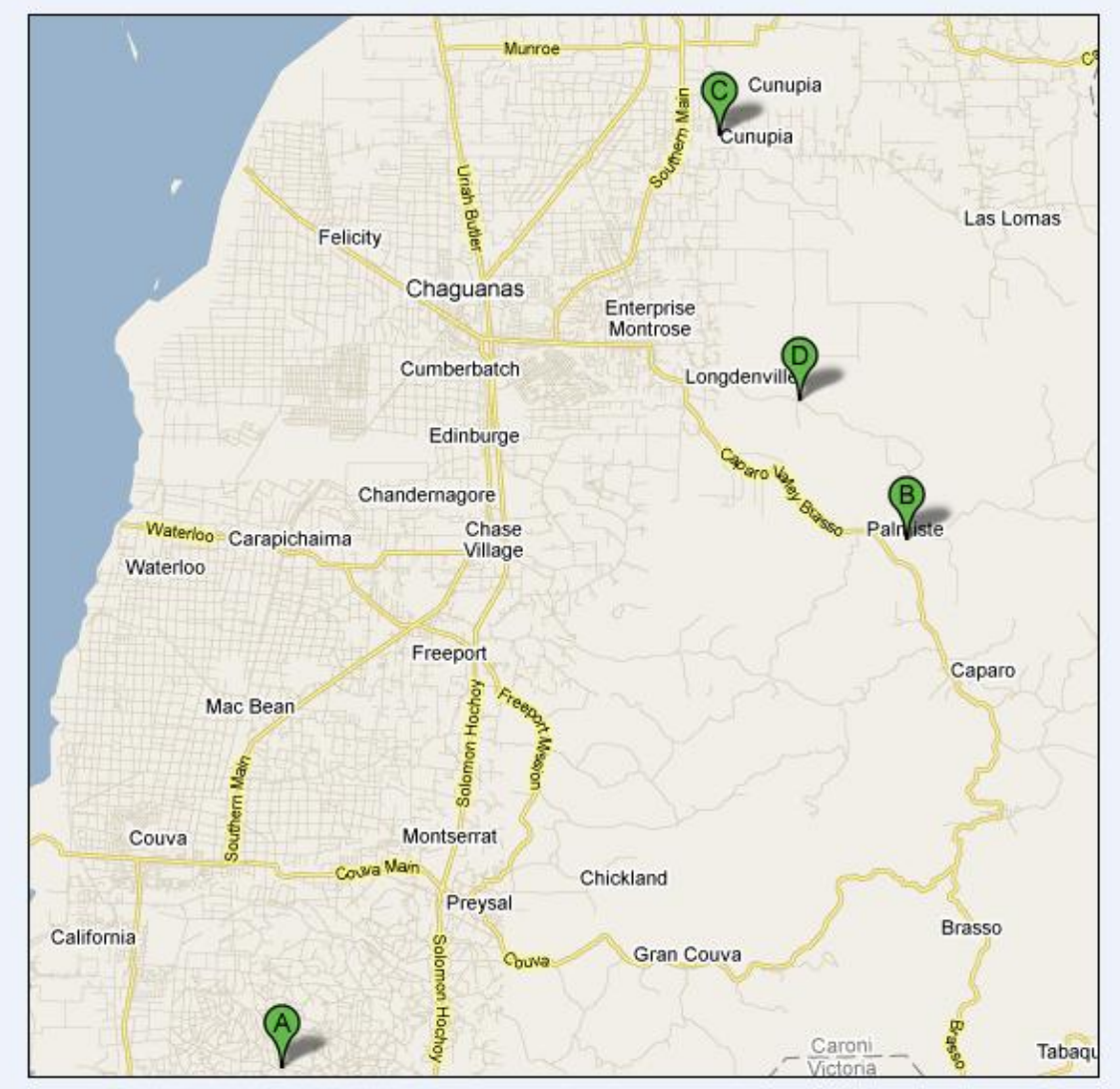

Figure 1 Blood Sampling at goat farm locations of Central and South Central Trinidad

A - Couva Farm; B- Palmiste farm; C- Cunupia Farm; D- Sugar Cane Feeds Center, Longdenville 


\subsection{Sample Collection}

Blood samples were collected from 153 goats of various physiological stages in the dry (April - May) and wet (November - December) seasons at the four locations (Table 3). Blood samples were collected from growing females (6 - 12 month old), dry late pregnant (four months), early lactating (up to 8 weeks of lactation) and dry non-pregnant goats (1 - 4 years old). Samples were taken from different animals at the same location in the dry and wet seasons. For haematologic analysis, $5 \mathrm{ml}$ of blood was collected by venipuncture using $18 \mathrm{~mm}$ gauge needles and placed into bottles containing approximately $0.5 \mathrm{mg} / \mathrm{ml} \mathrm{K}_{2}$ EDTA (Potassium ethylene diamine tetra acetic acid) as an anticoagulant. Ten (10) milliliters of blood were also collected from each animal,placed into acid-washed demineralised tubes and allowed to clot. The clotted blood was centrifuged within 4 hours of collection to remove the serum which was then stored at $-20^{\circ} \mathrm{C}$. Eighteen and 22 grass composite grass samples in the dry and wet seasons were collected from the Cunupia $(n=9)$, Chaguanas $(n=10)$, Sugar Cane Feeds Centre $(n=11)$ and Couva $(n=10)$ farm locations (Figure 1) Grasses were ovendried at $60^{\circ} \mathrm{C}$ in a forced draught oven to constant weight and hammer milled in a stainless steel mill to pass through a $1 \mathrm{~mm}$ sieve.

\subsection{Copper Analyses}

One milliliter of serum was diluted with $1 \mathrm{ml}$ deionized water in duplicates and determined by flame atomic absorption spectroscopy according to Fick et al. (1979), using a Pye Unicam 2900 Atomic Absorption Spectrophotometer equipped with a PU9090 data graphics system. Forage samples were collected, oven dried, milled, ashed at $550{ }^{\circ} \mathrm{C}$, and then solubilized using $10 \% \mathrm{HCL}$ and $50 \% \mathrm{HCL}$. Forage $\mathrm{Cu}$ was determined similarly in $\mathrm{mg} / \mathrm{kg} \mathrm{DM}$ according to Fick et al. (1979).

\subsection{Hematological Tests}

Haemoglobin concentration $(\mathrm{g} / \mathrm{L})$, mean corpuscular haemoglobin $(\mathrm{pg})$ and white blood cell counts $\left(10^{9} / \mathrm{L}\right)$, were obtained by the use of an automated Sysmex L4500 Haematology Analyzer (Channel 4) (Systemex, CA., USA). The differential leukocyte count (\%) was done on a Wright's-Giemsa stained blood smear (i.e. the number of each leukocyte type in a total of 100 white blood cells) (Thrall, 2004). Reticulocyte percentages were calculated for animals with low haemoglobin $(<80 \mathrm{~g} / \mathrm{L})$ and PCV $(<22$ $\%)$ values (Thrall, 2004). The stained blood smears from all animals were also examined for morphological abnormalities. Plasma fibrinogen levels $(\mathrm{g} / \mathrm{L})$ were determined by Millar's heat precipitation method (Jain, 1986).

\subsection{Statistical Analysis}

Hematological and serum $\mathrm{Cu}$ means were tested between seasons, among farm locations, and physiological stages, including the interactions of physiological stage $\mathrm{X}$ season and Location $\mathrm{X}$ season. Forage copper means were tested among locations and between seasons. This procedure was carried out by analysis of variance using Genstat Release 18.1 ( PC/Windows 8) 23 December 2015 22:39:42 Copyright 2015, VSN International Ltd. Significantly different means were compared using the protected Fishers LSD $(\mathrm{P}<0.05)$ test.

\section{Results}

\subsection{Red blood cell values and copper levels in the dry and wet seasons and among physiological stages}

Goats had lower $(\mathrm{P}<0.01)$ haemoglobin and PCV values in the wet than in the dry season (Tables 1 and 2). A higher percentage of goats had low haemoglobin $(<80 \mathrm{~g} / \mathrm{L})$ and packed cell volume $(<0.22$ $\mathrm{L} / \mathrm{L})$ values at the end of the wet $(41 \%)$ than in the dry $(26 \%)$ season. Low haemoglobin and PCV values in goats ranged from $45-75 \mathrm{~g} / \mathrm{L}$ and $0.13-0.21 \mathrm{~L} / \mathrm{L}$ respectively, in both seasons, with accompanying low reticulocyte counts $(<1 \%)$. Hemoglobin and PCV values also varied $(\mathrm{P}<0.001)$ among physiological stages, location and season in goats (Tables 1). Growing goats had higher $(\mathrm{P}<0.001)$ haemoglobin and PCV values than those of pregnant, lactating and dry non-pregnant goats (LSD P $<0.05$ ). There was a high incidence of anaemia (evidenced by low haemoglobin, PCV values and reticulocyte counts) in pregnant (34\%), lactating (43\%) and dry non-pregnant (44\%) goats when compared with growing animals $(18 \%)$.

Serum $\mathrm{Cu}(P<0.001)$, forage $\mathrm{Cu}(P<0.05), \mathrm{Hb}(P<0.001)$ and PCV $(P<0.001)$ levels also varied among farm locations (Table 1). The lowest forage $\mathrm{Cu}$ levels were found at the Cunupia and Couva 
locations. At the latter, the lowest serum $\mathrm{Cu}$ concentration was associated with lowest $\mathrm{Hb}$ and PCV values in goats. The lowest mean serum $\mathrm{Cu}$ level was associated with the highest incidences of nonregenerative anaemia (54\%) and of 75\% of copper levels below critical level BCL ( $<0.5 \mathrm{mg} / \mathrm{L}$ ) (Table 1). Fifty four percent of grasses had dietary insufficient copper levels below $5 \mathrm{mg} / \mathrm{KgDM}$ considered limiting for animal production and disease proneness.

\subsection{White Blood Cell and differential counts in the dry and wet seasons and among physiological stages}

Goats displayed somewhat similar incidences of eosinophilia $\left(>0.65 \times 10^{9} / \mathrm{L}\right)$ and basophilia $(>0.20 \mathrm{x}$ $10 \%$ L) (Bayers and Kramer, 2010) in the dry (40\% and 34\%) and wet season (46\% and 36\%), respectively. It should be noted that $7-9 \%$ of all goats and sheep displayed mild acanthocytosis $(+1$ to +2 ) as the only evidence of red blood cell abnormalities (poikilocytosis).

Variations occurred among the different physiological stages in goats with the white blood cell $(\mathrm{P}<0.05)$ and lymphocyte counts $(\mathrm{P}<0.01)$, with a physiological stage $\mathrm{x}$ season interaction $(\mathrm{P}<0.05$ (Table 1) in the white blood cell count (Tables 1 and 2). The physiological stage $\mathrm{x}$ season interaction showed that there were higher white blood cell counts in growing kids in both seasons compared to lower values in pregnant animals in the dry season, and lower values in non-pregnant animals in the wet season (LSD $\mathrm{P}<0.05)$ (Table 3). Lymphocyte counts were highest in growing goats $(\mathrm{P}<0.001)$ compared with other physiological stages (Tables 1). The lymphocyte: neutrophil ratio was highest in growing goats $\left(1.8 \times 10^{9} / \mathrm{L}\right)$ compared with other physiological stages $\left(0.9-1.1 \times 10^{9} / \mathrm{L}\right)$. Low to moderate incidences of eosinophilia $\left(>0.65 \times 10^{9} / \mathrm{L}\right)$ and basophilia $\left(>0.20 \times 10^{9} / \mathrm{L}\right)$ were exhibited by all physiological stages of goats (Jackson, 2007). In goats, protein $(\mathrm{P}<0.001)$ but not fibrinogen $(\mathrm{P}>0.05)$ levels differed among physiological stages. Mean plasma protein concentration was higher in lactating goats compared to growing and pregnant animals (LSD P $<0.05$ ), and $43 \%$ of lactating goats had mildly elevated protein levels above $75 \mathrm{~g} / \mathrm{L}$.

Significant variations also occurred among locations for the WBC counts $(\mathrm{P}<0.05)$, for the differential counts for lymphocytes $(\mathrm{P}<0.001)$, eosinophils $(\mathrm{P}<0.001)$, monocytes $(\mathrm{P}<0.05)$, basophils $(\mathrm{P}<0.01)$, and for the plasma protein $(\mathrm{P}<0.05)$ and fibrinogen levels $(\mathrm{P}<0.01)$ (Table 1$)$. The highest eosinophil and basophil counts and plasma protein levels were found at the Couva location.

\section{DisCUSSION}

Low forage and serum $\mathrm{Cu}$ levels below is good indicator of dietary insufficiency (Suttle, 2010). In this study a high percentage of goats had serum $\mathrm{Cu}$ levels below critical level which can compromise growth and performance, and lead to the development of anaemia and increased susceptibility to disease. The Couva location had the lowest forage and serum copper below critical level (BCL) with an accompanying highest percentage of moderate non-regenerative anaemia. This finding is the first farm level report substantiating the experimental induction of anaemia using semi purified diets with less than 1ppm Cu (Mills et al., 1976). The highest allergic response was also found at this location. Although determinations of parasitic infection was not carried out parasitism is also suspected of contributing to the anaemia encountered.

Although serum $\mathrm{Cu}$ was not affected by season in goats per se, similarly low serum $\mathrm{Cu}$ levels were found in both seasons, with significantly lower levels in lactating goats in the wet season. The lower serum $\mathrm{Cu}$ levels in lactating goats in the wet season compare somewhat with the non-significant decline in plasma $\mathrm{Cu}$ found in lactating goats in the wetter winter months in Pakistan (Khan et al., 2007). In this study a low to moderate percentage of adult and apparently normal animals had low Hemoglobin and PCV levels more so at the end of the wet than at the end of the dry season.

The anaemia observed in this study could have been due to reduced activity of the Cu-containing enzymes ceruloplasmin, cytochrome $\mathrm{C}$ oxidase, and hephasestin due to $\mathrm{Cu}$ deficiency, as these enzymes are involved in the transport of iron for erythropoiesis.

It has also has been suggested that that the anaemia associated with copper deficiency is more a problem of iron utilization rather than iron transport to the bone marrow (Prohaska, 2011). In this study there was a possible association between deficient $\mathrm{Cu}$ levels and the moderate incidence of anaemia manifesting in both seasons and at various physiological stages in goats and at one particular location. The lower haemoglobin and PCV values found in goats in the wet compared with the dry 
season were similar to those for Nigerian sheep breeds (Adewuyi and Adu, 1984). Contrastingly, Mahieu et al. (2007) reported lower PCV values during the dry than the wet season in pregnant and early lactating Creole goats from Guadeloupe. However, 39\% of Creole pregnant and lactating goats were found to be anaemic which compares with the findings in this study. In this study haemoglobin and PCV values were not significantly different between late pregnant and early lactating goats. In another study, it was found that blood values in sequentially monitored sheep and goats generally reflected a rise in these values in late gestation and parturition, declining in the periparturient period, and declining further in early lactation (El Sherif and Assad, 2001; Iriadam, 2007; Mohammed et al., 2014; Sharma et al., 2015; Manat et al., 2016). Animals in sequential studies are usually managed under experimental conditions such as similar diets and adequate anthelmintic control which were not controlled in this study. Also, dry non- pregnant goats on a proper plane of nutrition should exhibit a rise in haemoglobin and packed cell volume values instead of the moderate anemia reported here (Mbassa and Poulsen, 1991). The anemia found in pregnant and lactating goats is also probably related to an increase in plasma volume in late gestation (Jain, 1986) and to milk yield changes in early lactation (El-Deen et al., 1985b; Mbassa and Poulsen, 1991). The mild acanthocytosis observed in a low percentage of goats in this study may be an occasional finding in goats or may be dietary related (Jackson, 2007; Polizopoulou, 2010).

Young growing goats had the highest haemoglobin and PCV values, and white blood cell counts and lymphocyte counts compared to the goats in other the physiological stages. This is likely age-related (Nettleton and Beckett, 1976; Mbassa and Poulsen, 1991; 1992; Egbe-Nwiyi et al., 2000; Mohammed et al., 2014). The reversal of the lymphocyte: neutrophil ratios in growing goats is also probably age or stress related (Jain, 1986; Urquhart et al., 2007). Similarly, the reversal of the ratios in growing to pregnant and lactating goats is also age or stress related. The mild leukocytosis found in this study in pregnant and lactating goats is probably stress related (Polizopoulou 2010), and is also reported in similar studies in the tropics (Oduye, 1976; El- Deen et al., 1985b; Obidike et al., 2009). The higher plasma protein levels observed here in lactating goats is probably related to mild dehydration or a rise in $\gamma$-globulin levels in early lactation (Jain, 1986). Most of the goats of all physiological ages had plasma fibrinogen levels within expected ranges (Jain, 1986).

\section{Conclusions}

The purpose of this research was to study the effects of season and physiological stage on serum $\mathrm{Cu}$ levels and on certain red and white blood cell and plasma parameters of apparently normal goats of Central Trinidad. There was a higher incidence of anaemia in goats in the wet than in the dry season and an accompanying high incidence of $\mathrm{Cu}$ deficiency, indicative of dietary $\mathrm{Cu}$ insufficiency in both seasons. Hence there was a possible association between deficient $\mathrm{Cu}$ levels and the moderate to low incidence of anaemia manifesting in the wet season in goats. The anaemia manifested mostly at adult physiological stages in this species. Note that, at a particular farm location lowest forage and serum copper levels and an accompanying highest incidence of non-regenerative anaemia was observed. Dietary $\mathrm{Cu}$ insufficiency in affected animals could have affected growth, performance and their proneness to disease inclusive of the anaemia manifested. Accompanying the anaemia in the goats was a low to moderate eosinophilia and basophilia. These could be indicators of an allergic response may be due to parasitism. Goats also exhibited mostly normal physiological variations of hematological values toward stage of development. Based on the findings in this study, copper supplementation should be implemented for goats and sheep of Central Trinidad.

\section{ETHICS APPROVAL}

The research protocols for this study were approved by the Veterinary Ethics committee of the Faculty of Medical Sciences, The University of the West Indies.

\section{CONFLICT OF INTERESTS}

There was no conflict of interests of funding of commercial entities mentioned in this research.

\section{ACKNOWLEDGMENTS}

Special thanks are due to the following farmers: Simone King of the Cunupia farm, Vishnu Lalla of the Couva farm, and Dr. Gorie Lalla of the Chaguanas farm. We would also like to thank the farmhands who assisted in the various collections done at the Sugarcane Feeds Centre. Special thanks are also due to Ms. Beverly Moors of the school of Veterinary Medicine, who assisted us in carrying out the various blood analyses. 
The Association of Serum and Forage Copper Levels and Blood Values of Grazing Goats of Different Physiological Stages Pertaining to Location in the Dry and Wet Seasons from Central Trinidad

\section{Tables}

Table 1. Haematological values and serum and forage copper levels at goat farms pertaining to physiological stage, location and season

\begin{tabular}{|c|c|c|c|c|c|c|c|c|c|c|c|c|c|c|c|c|c|c|c|c|c|c|c|}
\hline \multirow[b]{3}{*}{ Parameter } & \multicolumn{8}{|c|}{ Location } & \multicolumn{8}{|c|}{ Physiological stage } & \multicolumn{4}{|l|}{ Season } & \multicolumn{3}{|c|}{ 'Significance } \\
\hline & \multicolumn{2}{|c|}{$\begin{array}{l}\text { Cunupia } \\
(n=32)\end{array}$} & \multicolumn{2}{|c|}{$\begin{array}{l}\text { Chaguanas } \\
(n=31)\end{array}$} & \multicolumn{2}{|c|}{$\begin{array}{l}\text { Sugar Cane } \\
\text { Feeds centre } \\
(n=33)\end{array}$} & \multicolumn{2}{|l|}{\begin{tabular}{|l|} 
Couva \\
$(n=57)$
\end{tabular}} & \multicolumn{2}{|c|}{$\begin{array}{l}\text { Growing } \\
(n=51)\end{array}$} & \multicolumn{2}{|c|}{\begin{tabular}{|l} 
Late \\
Pregnant \\
$(n=35)$
\end{tabular}} & \multicolumn{2}{|c|}{\begin{tabular}{|l|} 
Early \\
Lactating \\
$(n=35)$
\end{tabular}} & \multicolumn{2}{|c|}{\begin{tabular}{|l|} 
Dry non \\
Pregnant \\
$(n=32)$
\end{tabular}} & \multicolumn{2}{|l|}{$\begin{array}{l}\text { Dry } \\
(n=77)\end{array}$} & \multicolumn{2}{|l|}{$\begin{array}{l}\text { Wet } \\
(n=76)\end{array}$} & \multirow[t]{3}{*}{$\begin{array}{l}\text { Phys. } \\
\text { Stage }\end{array}$} & \multirow[t]{3}{*}{$L o c$} & \multirow[t]{3}{*}{ Seas } \\
\hline & Mean & $\pm \mathrm{SE}$ & Mean & $\pm \mathrm{SE}$ & Mean & $\pm \mathrm{SE}$ & Mean & $\pm \mathrm{SE}$ & Mean & $\pm \mathrm{SE}$ & Mean & $\pm \mathrm{SE}$ & Mean & $\pm \mathrm{SE}$ & Mean & $\pm \mathrm{SE}$ & Mean & $\pm \mathrm{SE}$ & Mean & $\pm \mathrm{SE}$ & & & \\
\hline $\begin{array}{l}\text { Red Blood } \\
\text { Cell }\end{array}$ & & & & & & & & & & & & & & & & & & & & & & & \\
\hline $\begin{array}{l}\text { Serum } C u \\
m g / L\end{array}$ & $0.53^{\mathrm{a}}$ & 0.03 & $0.58^{\mathrm{a}}$ & 0.04 & $0.46^{\mathrm{b}}$ & 0.03 & $0.35^{\mathrm{c}}$ & 0.03 & 0.47 & 0.03 & 0.44 & 0.03 & 0.44 & 0.03 & 0.48 & 0.03 & 0.48 & 0.02 & 0.44 & 0.02 & NS & *** & NS \\
\hline $\begin{array}{l}\text { \% Cu BCL } \\
\text { Forage Cu } \\
\text { g/kgDM }\end{array}$ & $\begin{array}{l}37.5 \% \\
4.67^{\circ} \\
(\mathrm{n}=9)\end{array}$ & 1.33 & $\begin{array}{l}55 \% \\
8.29^{\mathrm{a}} \\
(\mathrm{n}=10)\end{array}$ & 1.33 & $\begin{array}{l}57.5 \% \\
6.31^{\mathrm{b}} \\
(\mathrm{n}=11)\end{array}$ & 1.33 & $\begin{array}{l}75 \% \\
4.56^{\mathrm{c}} \\
(\mathrm{n}=10)\end{array}$ & 1.33 & NA & & NA & & NA & & NA & & $\begin{array}{l}5.7 \\
(\mathrm{n}=18\end{array}$ & 0.95 & $\begin{array}{l}6.2 \\
(\mathrm{n}=22)\end{array}$ & 0.95 & NA & $*$ & NS \\
\hline $\mathrm{Hbg} / \mathrm{L}$ & $94.2^{b}$ & 2.36 & $101^{\mathrm{a}}$ & 2.99 & $87.3^{\mathrm{c}}$ & 2.27 & $76.6^{d}$ & 1.82 & $93.9^{\mathrm{a}}$ & 1.92 & $85.1^{b}$ & 2.47 & $82.4^{b}$ & 2.6 & $83.7^{\mathrm{b}}$ & 2.26 & $91.4^{\mathrm{a}}$ & 1.65 & $82.8^{\mathrm{b}}$ & 1.60 & **** & **** & **** \\
\hline$P C V L / L$ & $0.28^{\mathrm{b}}$ & 0.01 & $0.31^{\mathrm{a}}$ & 0.01 & $0.26^{\mathrm{c}}$ & 0.01 & $0.23^{d}$ & 0.01 & $0.28^{\mathrm{a}}$ & 0.01 & $0.25^{\mathrm{b}}$ & 0.01 & $0.25^{\mathrm{b}}$ & 0.01 & $0.25^{\mathrm{b}}$ & 0.01 & $0.27^{\mathrm{a}}$ & 0.01 & $0.25^{\mathrm{b}}$ & 0.01 & **** & **** & **** \\
\hline$M C H C g / L$ & 334.7 & 1.84 & 330.6 & 2.34 & 336.2 & 1.77 & 334.5 & 1.42 & 334 & 1.5 & 334.2 & 1.93 & 334.6 & 2.03 & 334.2 & 1.77 & 334.6 & 1.29 & 333.8 & 1.22 & NS & NS & NS \\
\hline $\begin{array}{l}\% \text { anaemia } \\
\text { White blood } \\
\text { ell }\left(X \quad 10^{9} / L\right)\end{array}$ & $16 \%$ & & $26 \%$ & & $27 \%$ & & $54 \%$ & & & & & & & & & & & & & & & & \\
\hline$W B C$ & $15.9^{\mathrm{a}}$ & 0.71 & $13.9^{\mathrm{ab}}$ & 0.89 & $12.5^{\mathrm{b}}$ & 0.68 & $13^{\mathrm{b}}$ & 0.55 & $14.7^{\mathrm{a}}$ & 0.58 & $13.3^{\mathrm{b}}$ & 0.74 & $13.5^{\mathrm{b}}$ & 0.78 & $12.9^{\mathrm{b}}$ & 0.68 & 13.8 & 0.49 & 13.6 & 0.47 & *** & * & NS \\
\hline Neutrophils & 58 & 0.42 & 4.9 & 0.54 & 5.5 & 0.41 & 5.2 & 0.33 & 4.9 & 0.34 & 5.3 & 0.44 & 6.3 & 0.47 & 5.3 & 0.41 & 5.2 & 0.29 & 5.5 & 0.28 & NS & NS & NS \\
\hline Lymphocytes & $8.3^{\mathrm{a}}$ & 0.47 & $7.7^{\mathrm{a}}$ & 0.59 & $5.9^{b}$ & 0.45 & $5.5^{\mathrm{b}}$ & 0.36 & $8.7^{\mathrm{a}}$ & 0.38 & $5.9^{b}$ & 0.49 & $5.1^{b}$ & 0.52 & $5.3^{\mathrm{b}}$ & 0.45 & 7.0 & 0.33 & 6.1 & 0.31 & ***** & **** & NS \\
\hline Eosinophil & $0.5^{\mathrm{b}}$ & 0.15 & $0.2^{\mathrm{b}}$ & 0.19 & $0.6^{b}$ & 0.15 & $1.8^{\mathrm{a}}$ & 0.12 & 0.7 & 0.13 & 0.9 & 0.16 & 0.9 & 0.17 & 1.2 & 0.15 & 0.8 & 0.11 & 1.1 & 0.1 & NS & *** & NS \\
\hline Monocytes & $0.1^{\mathrm{b}}$ & 0.03 & $0.2^{\mathrm{a}}$ & 0.03 & $0.1^{\mathrm{b}}$ & 0.03 & $0.1^{\mathrm{b}}$ & 0.02 & 0.1 & 0.02 & 0.1 & 0.03 & 0.1 & 0.03 & 0.1 & 0.03 & 0.1 & 0.02 & 0.1 & 0.02 & NS & * & NS \\
\hline Basophils & $0.1^{\mathrm{b}}$ & 0.05 & $0.2^{\mathrm{ab}}$ & 0.07 & $0.2^{\mathrm{ab}}$ & 0.05 & $0.3^{\mathrm{a}}$ & 0.04 & 0.2 & 0.04 & 0.2 & 0.05 & 0.2 & 0.06 & 0.3 & 0.05 & 0.2 & 0.04 & 0.2 & 0.03 & NS & ** & NS \\
\hline $\begin{array}{l}\text { Plasma } \mathrm{g} / \mathrm{l} \\
\text { components }\end{array}$ & & & & & & & & & & & & & & & & & & & & & & & \\
\hline Protein & $75.9^{b}$ & 1.06 & $76.1^{b}$ & 1.35 & $74.4^{b}$ & 1.02 & $77.7^{\mathrm{a}}$ & 0.82 & $73.8^{\mathrm{a}}$ & 0.87 & $75.3^{\mathrm{bc}}$ & 1.11 & $80.5^{\mathrm{a}}$ & 1.17 & $77.5^{\mathrm{c}}$ & 1.02 & 76.4 & 0.74 & 76.22 & 0.71 & **** & * & NS \\
\hline Fibrinogen & $2.8^{\mathrm{b}}$ & 0.22 & $3.5^{\mathrm{a}}$ & 0.28 & $2.8^{\mathrm{b}}$ & 0.22 & $2.6^{b}$ & 0.17 & 3.1 & 0.18 & 2.7 & 0.24 & 2.8 & 0.25 & 2.7 & 0.22 & 2.8 & 0.16 & 2.9 & 0.15 & NS & *** & NS \\
\hline
\end{tabular}

${ }^{\text {a }}$ Below Critical Level (BCL) $\mathrm{Cu}<0.5 \mathrm{mg} / \mathrm{L}$; ${ }^{\mathrm{b}}$ Anaemia: $\mathrm{Hb}<75 \mathrm{~g} / \mathrm{L}$; PCV $<0.24 \mathrm{~L} / \mathrm{L}$ Means with different superscripts significantly different at $\mathrm{P}<0.05$, protected fishers LSD test ${ }^{\mathrm{x}}$ Significance $* \mathrm{P}<0.05$; $* * \mathrm{P}<0.01 ; * * * \mathrm{P}<0.001$, Ns Not Significant NA not applicable

Table 2. Haematological means of different physiological stages in goats in the dry and wet seasons of Central Trinidad

\begin{tabular}{|c|c|c|c|c|c|c|c|c|c|c|}
\hline Blood & \multicolumn{2}{|c|}{ Growing } & \multicolumn{2}{|c|}{ Late Pregnant } & \multicolumn{2}{|c|}{ Early Lactating } & \multicolumn{3}{|c|}{ Dry Non-Pregnant } & \multirow[t]{2}{*}{ Significance } \\
\hline Parameters & Dry & Wet & Dry & Wet & Dry & Wet & & & & \\
\hline $\begin{array}{l}n \\
\text { Parameter }\end{array}$ & 25 & 26 & 20 & 15 & 16 & 19 & 16 & 16 & $L S D$ & ${ }^{x}$ Signific. \\
\hline Red Blood Cells & & & & & & & & & & \\
\hline $\begin{array}{l}\text { Haemoglobin } \\
(\mathrm{g} / \mathrm{L})\end{array}$ & 105.2 & 90.4 & 82.5 & 83.7 & 85.6 & 75.3 & 87.5 & 83.2 & 10.71 & NS \\
\hline $\begin{array}{l}\text { Packed cell volume } \\
(L / L)\end{array}$ & 0.32 & 0.27 & 0.24 & 0.25 & 0.26 & 0.23 & 0.26 & 0.25 & 0.033 & NS \\
\hline $\begin{array}{l}\text { Mean corpuscular } \\
\text { Haemoglobin } \\
(\mathrm{g} / \mathrm{L})\end{array}$ & 332 & 334 & 338 & 333 & 334 & 335 & 335 & 332 & 6.6 & NS \\
\hline
\end{tabular}


Aphzal Mohammed et al.

\begin{tabular}{|c|c|c|c|c|c|c|c|c|c|c|}
\hline Serum $\mathrm{Cu}(\mathrm{mg} / \mathrm{L})$ & $0.44^{\mathrm{ab}}$ & $0.55^{\mathrm{b}}$ & $0.43^{\mathrm{ab}}$ & $0.42^{\mathrm{ab}}$ & $0.52^{\mathrm{b}}$ & $0.30^{\mathrm{a}}$ & $0.53^{\mathrm{b}}$ & $0.47^{\mathrm{b}}$ & 0.145 & $*$ \\
\hline \multicolumn{11}{|l|}{$\frac{\text { White Blood Cells }}{\left(x \quad 10^{9} / L\right)}$} \\
\hline $\begin{array}{l}\text { White blood cell } \\
\text { count }\end{array}$ & $15.1^{\mathrm{b}}$ & $15.2 b$ & $13.1^{\mathrm{ab}}$ & $14.0^{b}$ & $13.5^{\mathrm{b}}$ & $13.9^{b}$ & $14.8^{\mathrm{b}}$ & $10.7^{\mathrm{a}}$ & 2.70 & * \\
\hline Neutrophil & 4.8 & 4.8 & 4.9 & 6.1 & 6.4 & 6.2 & 5.5 & 5.0 & 1.57 & NS \\
\hline Lymphocyte & 9.2 & 8.7 & 6.0 & 5.8 & 5.1 & 5.3 & 6.7 & 4.3 & 1.87 & NS \\
\hline Eosinophil & 0.43 & 0.81 & 1.18 & 1.00 & 0.89 & 1.46 & 1.09 & 0.96 & 0.67 & NS \\
\hline Monocyte & 0.14 & 0.13 & 0.078 & 0.11 & 0.17 & 0.06 & 0.08 & 0.06 & 0.10 & NS \\
\hline Basophil & 0.26 & 0.17 & 0.24 & 0.14 & 0.22 & 0.17 & 0.19 & 0.22 & 0.19 & NS \\
\hline \multicolumn{11}{|l|}{$\begin{array}{l}\text { Plasma } \\
\text { components }\end{array}$} \\
\hline Protein $(g / L)$ & 74.4 & 73.2 & 76.1 & 73.73 & 78.8 & 82.6 & 77.2 & 78.1 & 4.00 & $\mathrm{NS}$ \\
\hline \begin{tabular}{|l} 
Fibrinogen $(g / L)$ \\
\end{tabular} & 3.0 & 3.5 & 2.4 & 2.9 & 2.9 & 2.3 & 2.9 & 2.7 & 0.77 & NS \\
\hline
\end{tabular}

Means with different superscripts significantly different at $\mathrm{P}<0.05$, protected Fishers LSD test ${ }^{\mathrm{x}}$ Significance $* \mathrm{P}<0.05$; NS, Not significant

Table 3. Haematological values and serum and forage copper levels of goats in the wet and dry seasons at various farm locations

\begin{tabular}{|c|c|c|c|c|c|c|c|c|c|c|c|}
\hline \multirow{2}{*}{\begin{tabular}{|c|} 
Location \\
Season \\
\end{tabular}} & \multicolumn{2}{|c|}{ Cипиріа } & \multicolumn{2}{|c|}{ Chaguanas } & \multicolumn{2}{|c|}{$\begin{array}{l}\text { Sugar Cane } \\
\text { FeedsCentre }\end{array}$} & \multicolumn{2}{|c|}{ Couva } & \multicolumn{3}{|c|}{${ }^{x}$ Significance } \\
\hline & $\begin{array}{c}\text { Dry } \\
(n=16)\end{array}$ & $\begin{array}{c}\text { Wet } \\
(n=16)\end{array}$ & $\begin{array}{c}\text { Dry } \\
(n=15)\end{array}$ & $\begin{array}{c}\text { Wet } \\
(n=16)\end{array}$ & $\begin{array}{c}\text { Dry } \\
(n=16)\end{array}$ & $\begin{array}{c}\text { Wet } \\
(n=17)\end{array}$ & $\begin{array}{c}\text { Dry } \\
(n=30)\end{array}$ & $\begin{array}{c}\text { Wet } \\
(n=27)\end{array}$ & Loc & $\begin{array}{c}\text { Seaso } \\
n\end{array}$ & $\begin{array}{l}\text { Loc. } X \\
\text { Seas. }\end{array}$ \\
\hline \multicolumn{12}{|l|}{ Red blood cell } \\
\hline Serum Cu $\mathrm{mg} / \mathrm{Kg}$ & $0.58^{\mathrm{a}}$ & $0.49^{\mathrm{b}}$ & $0.54^{\mathrm{a}}$ & $0.62^{\mathrm{c}}$ & $0.35^{\mathrm{d}}$ & $0.56^{\mathrm{a}}$ & $0.45^{\mathrm{e}}$ & $0.26^{\mathrm{f}}$ & $* * *$ & NS & **** \\
\hline $\begin{array}{l}\text { Forage } \mathrm{Cu} g / \mathrm{Kg} D M \\
\text { Mean } \pm S D\end{array}$ & $\begin{array}{l}3.7 \pm 1.5 \\
3\end{array}$ & $\begin{array}{l}5.7 \pm 3.0 \\
6\end{array}$ & $\begin{array}{l}9.9 \pm \\
1.20\end{array}$ & $\begin{array}{l}7.0 \\
\pm 3.09\end{array}$ & $5.9 \pm 4.1$ & $6.4 \pm 2.07$ & $\begin{array}{l}3.7 \pm \\
1.6\end{array}$ & $\begin{array}{l}5.4 \pm \\
4.05\end{array}$ & & NS & NS \\
\hline $\mathrm{Hb} / \mathrm{L}$ & $96.49^{\mathrm{a}}$ & $91.92^{\mathrm{a}}$ & $110.96^{\mathrm{b}}$ & $88.36^{\mathrm{ac}}$ & $83.5^{\mathrm{c}}$ & $83.24^{\text {ac }}$ & $82.54^{c}$ & $70.52^{\mathrm{d}}$ & **** & $* * *$ & $* * *$ \\
\hline$P C V L / L$ & $0.29^{\mathrm{a}}$ & $0.28^{\mathrm{ac}}$ & $0.34^{\mathrm{b}}$ & $0.27^{\mathrm{ad}}$ & $0.25^{\mathrm{cd}}$ & $0.27^{\mathrm{ad}}$ & $0.24^{\mathrm{d}}$ & $0.21^{\mathrm{e}}$ & **** & **** & **** \\
\hline$M C H C g / L$ & $337.6^{\mathrm{a}}$ & $331.9^{\mathrm{a}}$ & $329.5^{\mathrm{a}}$ & $332.1^{\mathrm{a}}$ & $332.4^{\mathrm{a}}$ & $340^{\mathrm{ab}}$ & $337^{\mathrm{ab}}$ & $332.1^{\mathrm{a}}$ & NS & NS & * \\
\hline \multicolumn{12}{|l|}{$\begin{array}{l}\text { White blood cell }(X \\
\left.10^{9}\right)\end{array}$} \\
\hline$W B C$ & $15.33^{\mathrm{a}}$ & $16.6^{\mathrm{a}}$ & $13.25^{\text {ac }}$ & $14.91^{\mathrm{ab}}$ & $14.66^{\mathrm{ab}}$ & $10.36^{\mathrm{c}}$ & $12.76^{\mathrm{bc}}$ & $13.28^{\mathrm{ab}}$ & ** & NS & ** \\
\hline Neutrophils & $4.59^{\mathrm{a}}$ & $6.93^{\mathrm{b}}$ & $4.15^{\mathrm{a}}$ & $5.91^{\mathrm{ab}}$ & $6.85^{\mathrm{b}}$ & $4.13^{\mathrm{a}}$ & $5.16^{\mathrm{a}}$ & $5.28^{\mathrm{a}}$ & NS & NS & **** \\
\hline Lymphocytes & 8.37 & 821 & 7.27 & 8.16 & 6.38 & 5.38 & 3.53 & 4.38 & **** & NS & NS \\
\hline Eosinophil & $0.31^{\mathrm{a}}$ & $0.6^{\mathrm{a}}$ & $0.22^{\mathrm{a}}$ & $0.23^{\mathrm{ac}}$ & $0.89^{\mathrm{ab}}$ & $0.35^{\mathrm{ac}}$ & $1.32^{\mathrm{b}}$ & $2.21^{\mathrm{a}}$ & **** & NS & * \\
\hline Monocytes & 0.07 & 0.07 & 0.11 & 0.23 & 0.09 & 0.07 & 0.13 & 0.06 & * & NS & NS \\
\hline Basophils & 0.08 & 0.07 & 0.19 & 0.16 & 0.25 & 0.05 & 0.25 & 0.37 & $* *$ & NS & NS \\
\hline \multicolumn{12}{|l|}{ Protein components } \\
\hline Protein $\mathrm{g} / \mathrm{L}$ & $75.53^{\mathrm{a}}$ & $76.38^{\mathrm{a}}$ & $80.09^{\mathrm{ac}}$ & $71.01^{\mathrm{bd}}$ & $72.69^{\text {ad }}$ & $76.06^{\mathrm{ac}}$ & $76.92^{\mathrm{ac}}$ & $78.48^{\mathrm{ac}}$ & * & NS & ** \\
\hline Fibrinogen $g / L$ & 2.65 & 2.95 & 3.48 & 3.45 & 2.75 & 2.98 & 2.49 & 2.62 & ** & NS & NS \\
\hline
\end{tabular}

Means with different superscripts significantly different at $\mathrm{P}<0.05$, protected fishers LSD test ${ }^{\mathrm{X}}$ Significance $* \mathrm{P}<0.05$; $* *$ $\mathrm{P}<0.01 ; * * * \mathrm{P}<0.001$, Ns Not Significant 


\section{REFERENCES}

Adewuyi, A.A., and I.F. Adu. 1984. Seasonal variation in the levels of some blood components of indigenous and crossbred sheep. Tropical Animal Production 3: 223-230.

Ameen, S.A., R.A. Joshua, O.S. Adedeji, L.O. Ojedapo and S.R. Amao. 2010. Experimental Studies on Gastro-Intestinal Nematode Infection;The Effects of Age on Clinical Observations and Haematological Changes Following Haemonchus contortus Infection in West African Dwarf (WAD) Goats World Journal of Agricultural Sciences 6 (1): 39-43.

Azab, M.A. and H.A. Abdel-Maksoud. 1999. Changes in some hematological and biochemical parameters during prepartum and postpartum periods in female Baladi goats. Small Ruminant Research 34:87-85.

Bayers, S.R., and J.W. Kramer. 2010 Normal hematology of sheep and goats. In: D. J. Weiss and K. J. Wardrop (eds), Schalm's Veterinary Hematology. $6^{\text {th }}$ Ed. Blackwell Publishing Ltd, Iowa, USA, pp 836-842.

Egbe-Nwiyi, T.N., S.C. Nwaosu, and H.A. Salami. 2000 Hematological values of apparently healthy sheep and goats as influenced by age and sex in the arid zone of Nigeria. African Journal of Biomedical Research 3:109-115.

El-Deen, A.M., Z.R. Abo-Elezz, M.A. Samak, and G.A. Hassan. 1985 Variations in hematological characteristics of cross-bred goats (Baladi X Angora) during pregnancy, lactation and dry seasons. World Review of Animal Production 21:39-43.

El-Sherif, M.M.A., and F. Assad. 2001. Changes in some blood constituents of Barki ewes durng pregnancy and lactation under seim arid conditions. Small Ruminant Research 40:269-277.

Fick, K.R., McDowell, L.R., Miles, P.H., Wilkinson, N.S., Funk, J.P. and Conrad JH 1979. Methods of mineral analysis for plant and animal tissues. Animal Sciences Department, University of Florida, Gainesville, USA.

Habibu, B., M.U. Kawu, H.J. Makun, T. Aluwong, L.S. Yakub, M.S. Ahmad, M. Tauheed, and H.U. Buhari. 2014. Influence of sex, reproductive status and foetal number on erythrocyte osmotic fragility, haematological and physiologic parameters in goats during the hot-dry season. Veterinary Medicine Czech 59 (10): 479-490.

Howell, J.Mc.C. 1968b. The effect of experimental copper deficiency on growth, reproduction and hemopoiesis in the sheep. Veterinary Records 83:226-32.

Iriadam, M. 2007. Variation in certain hematological and biochemical parameters during the peripartum period in Kilis does. Small Ruminant Research 73: 54-57.

Jackson, M. 2007. Erythrocytes, Leucocytes. In: Veterinary Clinical Pathology an introduction. Blackwell Publishing, Iowa USA, 6 (27): 55-67.

Jain, N.C. 1986. Schalm's Veterinary Hematology. Lea and Febiger, Philadelphia

Lutu, W.Z. 1983. Internal parasitism in milk goats in Kenya. Tropical Animal Health and Production 16:153-157

Khan, Z.I., A. Hussain, M. Ashraf, M.Y. Ashraf, L.R. McDowell, and B. Huchzermeyer. 2007. Copper nutrition of goats grazing native and improved pasture with the seasonal in a semiarid region of Pakistan. Small Ruminant Research 67:138-148.

Mahieu, M., Arquet, R., Kandassamy, T., Mandonnet, M. and Hoste, H. 2007. Evaluation of targeted drenching using Famacha $\mathrm{C}$ method in Creole goat: Reduction of anthelmintic use and effects of kid production and pasture contamination. Vet. Paras. 146, 135-147.

Manat. T.D., S.S. Chaudhary, V.K. Singh, S.B. Patel, and G. Puri. 2016. Hematobiochemical profile in Surti goats during post-partum period. Veterinary World 9 (1): 19-24.

Mbassa, G.K., and J.S.D. Poulsen. 1991. Influence of pregnancy, lactation and environment on hematological profiles in Danish Landrace dairy goats (Capra hircus) of different parity. Comparative Biochemistry and Physiology 100 (2), 403-412.

Mbassa, G.K., and J.S.D. Poulsen. 1992. The comparative hematology of cross-bred and indigenous East African goats of Tanzania and breeds reared in Denmark. Veterinary Research Communications 16: 221-229. 
McDowell, L. R., and J.D. Arthington. 2005. Minerals for Grazing Ruminants in Tropical Regions. Animal Sciences Department, University of Florida, Gainesville, USA.

Mills, C.F., A.C. Dalgarno, and G. Wenham. 1976. Biochemical and pathological changes in tissues of Friesian cattle during experimental induction of copper deficiency. British Journal of Nutrition 21: 629- 633.

Mohammed, A. 1999. The mineral status and hematological Values of sheep and goats with reference to swayback in Trinidad. (Unpublished PhD thesis, The University of the West Indies)

Mohammed, A., M. Campbell, and F.G. Youssef. 2014. Serum copper and haematological values of sheep of different physiological stages in the dry and wet Seasons of Central Trinidad. Veterinary Medicine International. Article ID 972074, 7 pages. http://dx.doi.org/10.1155/2014/972074

Morris, J.S., and J.K. Dunn. 1992. Hematology. In Pract. 14(2): 67-72.

Njidda, A.A., A.A. Shuai'bu, and C. E. Isidahomen. 2014. Haematological and Serum Biochemical Indices of Sheep in Semi-Arid Environment of Northern Nigeria Global Journal of Science Frontier Research Online ISSN: 2249-4626 \& Print ISSN: 0975-58962014.

Nettleton, P., and P. Beckett. 1976. Hematology of the indigenous goat in Swaziland. Tropical Animal Health and Production 8: 60-61.

Obidike, I.R., L.O. Aka, and C.I. Okafor. 2009. Time dependent peripartum hematological, biochemical and rectal temperature changes in West African Dwarf ewes. Small Ruminant Research 82: 53-57.

Oduye, O.O. 1976. Hematological values of Nigerian goats and sheep. Tropical Animal Health and Production 8: 131-136.

Omeke B.C.O. 1988. Evaluation of three strategic prophylactic programmes against helminthiasis of traditionally managed West African dwarf sheep and goats in Nigeria. British Veterinary Journal 144: 590-595.

Prohaska, J.R. 2011. Impact of copper limitation on expression and function of multicopper oxidases (ferroxidases). Advances in Nutrition 2:129-137.

Polizopoulou, Z.S. 2010. Hematology and health management in sheep. Small Ruminant Research 92: 88-91.

Schalms Veterinary Haematology. 2010. Eds Douglas J .Weiss and Jane K. Wardrop Blackwell Publishing Ltd Iowa USA

Sharma, A., P. Kumar, M. Singh, and N.K. Vashishta. 2015. Haemato-biochemical and endocrine profiling of north western Himalayan Gaddi sheep during various physiological/reproductive phases. Open Veterinary Journal 5 (2):103-107.

Suttle, N.F. 2010. Copper. In The Mineral Nutrition of Livestock, $\left(4^{\text {rd }}\right.$ ed). Commonwealth Agricultural Bureaux UK, pp 255-305.

Thrall, M.A., D.C. Baker, and E.D. Lassen. 2004. Veterinary Haematology and Clinical Chemistry Lippincott Williams and Wilkins, Philadelphia, USA

Urquhart, G.M., J. Armour, J.L. Duncan, A.M. Dunn, and F.W. Jennings. 1996. Veterinary Parasitology ( $2^{\text {nd }}$ ed), (Blackwell Science Ltd, UK), pp 276.

Williams, D.M., Kennedy, F.S.and Green, B.G. 1985. The effect of iron substrate on mitochondrial haem synthesis in copper deficiency. British Journal of Nutrition 53:131-136. 
The Association of Serum and Forage Copper Levels and Blood Values of Grazing Goats of Different Physiological Stages Pertaining to Location in the Dry and Wet Seasons from Central Trinidad

\section{AUTHORS' BIOGRAPHY}

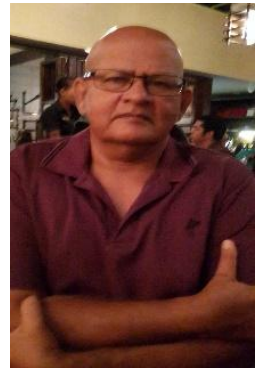

Dr. Aphzal Mohammed, completed a PHD on the pathology and haematology of copper deficiencies in goats and sheep. His present research interests are in anthelmintic resistance in small ruminants. He is also doing research on phytobiotics and probiotics to enhance performance in poultry and cattle.

Dr Mervyn Campbell, Dr. Mervyn Campbell is a board certified clinical veterinary pathologist. He formerly worked for many years as both a systemic and clinical pathologist at the School of Veterinary Medicine (SVM), UWI. He continues to publish with former post graduate students of the faculty in the area of Veterinary haematology.

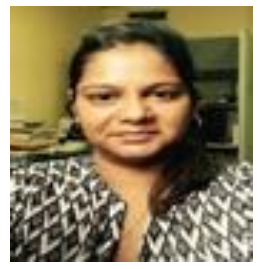

Dr Indira Pargass, is an American-board certified Veterinary Clinical Pathologist, who currently lectures to veterinary students at the School of Veterinary Medicine (SVM), UWI. She also is the lab coordinator of the Clinical Pathology laboratory at the SVM, and performs diagnostic work in the areas of haematology, biochemistry, cytology and urinalysis. Her primary interests are in collaborative research and diagnostics.

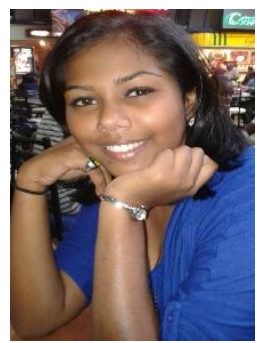

Ms. Shenese Sieuchand, Shenese Sieuchand is currently a research assistant at the University of Trinidad and Tobago and an MPhil candidate at the University of West Indies. Her research project is on marker assisted identification of gastrointestinal parasites causing anthelmintic resistance in small ruminants.

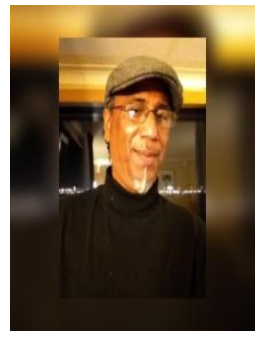

Dr. Puran Bridgemohan, Dr. Bridgemohan is a Biometrician, crop scientist; EU grant holder with research projects in phytochemistry of indigenous crop based products; selection of high capsaicin hot pepper varieties; and control of midges in cacoa production

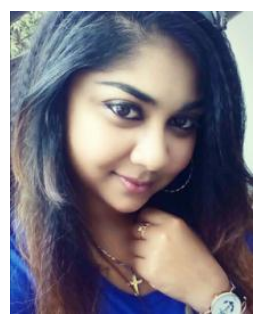

Ms. Angelisah Khan, Ms. Khan holds a Bachelor's Degree in Animal Science and Technology and is currently completing her Masters in Tropical Animal Science and Production. Her Master's research project is on the effects of Moringha olifiera essential oil inclusion on performance parameters in poultry.

Dr. Fayez G. Youssef, is a retired Animal Nutritionist and has previously worked on by product feeding, mineral nutrition and growth promoters in sheep. 